\title{
A multi-model, multi-scenario, and multi-domain analysis of regional climate projections for the Mediterranean
}

\author{
George Zittis $^{1}$ (D) Panos Hadjinicolaou ${ }^{1} \cdot$ Marina Klangidou ${ }^{1} \cdot$ Yiannis Proestos $^{1} \cdot$ Jos Lelieveld $^{1,2}$
}

Received: 12 February 2019 / Accepted: 20 September 2019/Published online: 25 November 2019

(C) The Author(s) 2019

\begin{abstract}
Observation and model-based studies have identified the Mediterranean region as one of the most prominent climate change "hot-spots." Parts of this distinctive region are included in several Coordinated Regional Downscaling Experiment (CORDEX) domains such as those for Europe, Africa, the Mediterranean, and the Middle East/North Africa. In this study, we compile and analyze monthly temperature and precipitation fields derived from regional climate model simulations performed over different CORDEX domains at a spatial resolution of $50 \mathrm{~km}$. This unique multi-model, multi-scenario, and multi-domain "super-ensemble" is used to update projected changes for the Mediterranean region. The statistical robustness and significance of the climate change signal is assessed. By considering information from more than one CORDEX domains, our analysis addresses an additional type of uncertainty that is often neglected and is related to the positioning of the regional climate model domain. CORDEX simulations suggest a general warming by the end of the century (between 1 and $5^{\circ} \mathrm{C}$ with respect to the 1986-2005 reference period), which is expected to be strongest during summer (up to $7^{\circ} \mathrm{C}$ ). A general drying (between 10 and $40 \%$ ) is also inferred for the Mediterranean. However, the projected precipitation change signal is less significant and less robust. The CORDEX ensemble corroborates the fact that the Mediterranean is already entering the $1.5^{\circ} \mathrm{C}$ climate warming era. It is expected to reach $2{ }^{\circ} \mathrm{C}$ warming well within two decades, unless strong greenhouse gas concentration reductions are implemented. The southern part of the Mediterranean is expected to be impacted most strongly since the CORDEX ensemble suggests substantial combined warming and drying, particularly for pathways RCP4.5 and RCP8.5.
\end{abstract}

Keywords Mediterranean $\cdot$ Climate change $\cdot$ CORDEX $\cdot$ Ensemble $\cdot$ Dynamical downscaling

\section{Introduction}

According to observational evidence and the vast majority of scientific literature, climate warming is considered unequivocal, while the attribution of this warming to anthropogenic activities is regarded as extremely likely (IPCC 2013a).

Marina Klangidou was formerly affiliated by The Cyprus Institute

Communicated by Marc J. Metzger

Electronic supplementary material The online version of this article (https://doi.org/10.1007/s10113-019-01565-w) contains supplementary material, which is available to authorized users.

George Zittis

g.zittis@cyi.ac.cy

1 Energy, Environment and Water Research Center, The Cyprus Institute, Nicosia, Cyprus

2 Department of Atmospheric Chemistry, Max Planck Institute for Chemistry, Mainz, Germany
Global warming impact is expected to be largest in regions where trends of temperature and precipitation have opposite sign (World Bank 2013). One such "hot-spot" region is the Mediterranean. A large number of climate reconstructions and observation-based studies and assessments corroborate this temperature increase, combined with changes in precipitation patterns (Luterbacher and Xoplaki 2003, Kuglitsch et al. 2010, Philandras et al. 2011, Hoerling et al. 2012, Lionello et al. 2012, Ulbrich et al. 2013, Cook et al. 2016, Zittis 2018). Moreover, the region is particularly sensitive to the variability and changes in the large-scale climate dynamics as it is located in a transitional zone between subtropical temperate and continental climates (WCRP 2013). Particularly after the 1980s, the rate of warming over the region has accelerated and is higher than the global average (Zittis and Hadjinicolaou 2017; Cramer et al. 2018; Lionello and Scarascia 2018).

Global climate models suggest that if the rate of emissions of greenhouse gases (GHGs) remain at present-day levels, these combined warming and drying trends will continue throughout the current century and will be further intensified 
(Giorgi and Lionello 2008; IPCC 2013b; Lelieveld et al. 2016). In addition, projected changes in the seasonal variability of temperature and rainfall for the region support the characterization of the Mediterranean as one of the most prominent global climate change hot spots (Giorgi 2006; Diffenbaugh and Giorgi 2012). Qualities of the Mediterranean Sea such as salinity, acidity, temperature, and sea level are also expected to increase due to a combination of atmospheric heating and decreased precipitation and river runoff in the basin (Adloff et al. 2015; Flecha et al. 2015). On top of changes in Mediterranean mean climatic conditions, extreme events such as heatwaves and prolonged droughts are expected to become more frequent and severe while some parts, particularly over the north of the region of interest, will likely experience more intense heavy precipitation events (Sánchez et al. 2004; Kundzewicz et al. 2006; Diffenbaugh et al. 2007; Giorgi et al. 2014; Jacob et al. 2014; Paxian et al. 2015; Zittis et al. 2016; Polade et al. 2017).

Considering these challenges, high-quality projections are needed in order to assess the impacts of climate change but also to show policy makers and societies the need for drastic mitigation and adaptation measures. Global earth system models are the essential tools in providing such information; however, due to the diverse characteristics within the Mediterranean Basin, more regionalized information is required. Such characteristics include the steep orographic and climate gradients, many and complex coastlines, alterations in land use, and the presence of islands and large urban centers. Moreover, regional models are often more appropriate for such climate studies, since local-scale processes are acting over the basin and drive the Mediterranean circulation dynamics (Li et al. 2011). A common technique for obtaining high-resolution climate projections is regional climate modeling through dynamical downscaling (Giorgi and Mearns 1999). The most comprehensive effort in coordinating regional climate projections throughout the globe is the Coordinated Regional Downscaling Experiment-CORDEX (http://www.cordex.org/). Fortunately, the Mediterranean region is one of the few regions globally that is included in several CORDEX domains. These are the European, African, Mediterranean, and Middle East/North Africa domains. This is of particular importance, since the positioning of the integration domain of a regional climate model can play a critical role in the simulation of meteorological processes (Giorgi and Gutowski 2016), while parts of the region of interest are located closely near the boundaries of some of the tested regional simulation domains.

The objective of the present work is to use the publicly available CORDEX archives of regional climate modelling information for the broader Mediterranean region in order to provide a comprehensive range of possible futures. The study focuses on annual and seasonal near-surface temperature and precipitation changes. This multi-model assessment provides additional insights and complement and support the existing information from global studies or assessments such as the 5th
Assessment Report (AR5) of the Intergovernmental Panel on Climate Change (IPCC). Our findings could additionally serve the needs and support pan-Mediterranean integrated risk assessment reports and initiatives such as the Mediterranean Experts on Environmental and Climate Change-MedECC (Cramer et al. 2018). Similar type of multi-model studies for parts of the region has already been performed (Giorgi and Lionello 2008; IPCC 2013b; Lelieveld et al. 2016; Lionello and Scarascia 2018). However, they are based on relatively coarse-resolution global models. In addition, the present contribution is an update in terms of future scenarios, including results for the less studied Representative Concentration Pathway RCP2.6, which has to be implemented in order to comply with the "first-line" Paris Agreement targets. Finally, we also assess the significance and robustness of the climate change signal, while climatic feedbacks that drive or enhance the projected changes are also discussed.

\section{Data and Methodology}

\section{Models, domains, and scenarios}

For this study, we analyzed model output of regional climate simulations performed as contributions to the CORDEX initiative (Giorgi and Gutowski 2015). As depicted in Fig. 1, parts of the Mediterranean are included in four CORDEX domains, namely the European: EURO-CORDEX (https:// www.euro-cordex.net/), Mediterranean: MED-CORDEX (https://www.medcordex.eu/), African: CORDEX-AFRICA (http://www.csag.uct.ac.za/cordex-africa/), and Middle East/ North Africa: MENA-CORDEX (http://mena-cordex.cyi.ac. cy/). For MED-CORDEX climate projections, where some coupled simulations (ocean and atmosphere) are available (Ruti et al. 2016; Somot et al. 2018), we only analyzed simulations from the non-coupled atmospheric models for

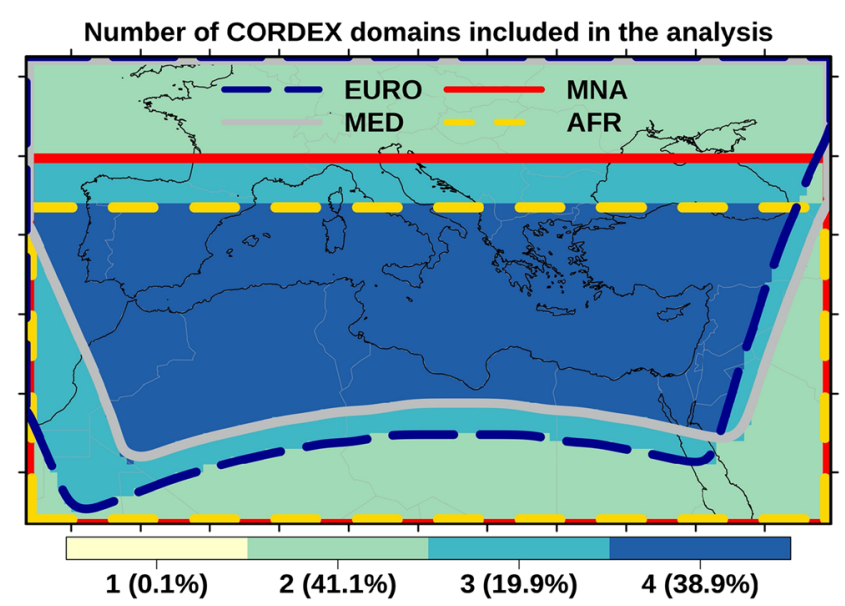

Fig. 1 Spatial extent of the study region and number of CORDEX domains included in the analysis. Outlines of each CORDEX domain within the study region are highlighted 
consistency with results from the other domains. For the analysis, we considered a broader Mediterranean domain that includes most of the extent of countries that have coastlines within the basin. This domain is defined as the area between $13.25^{\circ} \mathrm{W}$ and $44.75^{\circ} \mathrm{E}$ in longitude and $21.75^{\circ} \mathrm{N}$ and 51.25 ${ }^{\circ} \mathrm{N}$ in latitude. For about $59 \%$ of the region of interest, there is an overlap of at least three CORDEX domains while for the remaining $41 \%$, there is an overlap of two domains. Prior to the uploading of files in the CORDEX data portals, a number of grid points that make up the "sponge" buffer zone between the lateral boundary conditions and the actual simulation domain has been excluded.

We focus on two of the most important meteorological variables in terms of straightforward impacts, mean temperature near surface and precipitation. In addition to the mean temperature, monthly averages of daily maximum and minimum temperature are also analyzed. Data from CORDEXAFRICA, EURO-CORDEX, and MENA-CORDEX downscaling experiments were retrieved from the Swedish Earth System Grid Federation (ESGF) node (https://esg-dn1.nsc. liu.se/projects/esgf-liu/), while MED-CORDEX files were obtained through the MISTRALS (Mediterranean Integrated STudies at Regional And Local Scales) program data portal (http://mistrals.sedoo.fr/). An extensive quality check was performed in order to correct or exclude corrupted files (e.g., files with wrong units or missing time periods). The vast majority of CORDEX Phase I simulations is in a horizontal resolution of $0.44^{\circ}(\approx 50 \mathrm{~km})$. For consistency throughout the domains and experiments, we only analyzed model output of this resolution, despite the partial availability of higher resolution simulations over some CORDEX domains (e.g., EUR-11 or MED-11 experiments). Moreover, for the longerterm temporal statistics (e.g., seasonal, annual), which are of interest for the present study, the added value in higherresolution simulations is not always evident in current RCMs. For example, comparisons between $0.11^{\circ}$ and $0.44^{\circ}$ EURO-CORDEX experiments indicate no systematic temperature bias reduction in the high-resolution experiments, while for precipitation, seasonal mean biases can be larger in the higher-resolution EUR-11 set of simulations (Kotlarski et al. 2014; Soares and Cardoso 2018).

In terms of model configuration, the ensemble consists of 17 regional climate models (RCMs) and 14 global climate models (GCMs). Most GCMs are part of the 5th Coupled Model Intercomparison Project (CMIP5) and were also used in IPCC's AR5. Most simulations are from CORDEXAFRICA and EURO-CORDEX, since on one hand, Africa was the key-region of CORDEX phase I, while on the other hand, most modeling groups are active in Europe. The GCM/ RCM matrix for these two domains is almost identical (Table S1). Such merging of information derived from different CORDEX domains' simulations has been previously applied on a global scale study (Spinoni et al. 2019).
This "super-ensemble" consists of 62 combinations of $\mathrm{GCMs} / \mathrm{RCMs} /$ domains, forced under "historical" observed GHG concentrations and three "future" representative concentration pathways (RCPs) that resulted in a total of 188 simulations (Table S1). Sixty-two simulations cover the historical period 1951-2005 as defined by the CORDEX simulation protocol. For future climate projections (2006-2100), the majority follows pathways RCP8.5 and RCP4.5 (53 and 48, respectively). Only 24 simulations consider the more optimistic RCP2.6, which has to be implemented in order to reach the main targets set by the Paris Agreement and keep global warming to well below $2{ }^{\circ} \mathrm{C}$ since pre-industrial times. Noteworthy, in order to achieve the $1.5^{\circ} \mathrm{C}$ target, an even more aggressive mitigation scenario is required (Sanderson et al. 2016). According to IPCC (2013b), there is no consensus in the community about how to assign likelihood to different model projections. Consequently, the different combinations of CMIP5/CORDEX models included in this study are all considered to give equally likely projections in the sense of "one model, one vote." Regional models with variations in physical parameterization schemes are treated as distinct models. Simulations for the selected CORDEX domains were performed using different map projections. Therefore, in order to compile all available information, the model output had to be interpolated in a common grid. This was the grid of the CRU gridded observations (Harris et al. 2014) that were also used for a comparison with the simulated historical reference period of the recent past (see Supplementary Material). Although parts of the Mediterranean are often characterized by high observational uncertainty, CRU observations are found to be quite representative and accurate for most of the Mediterranean (Tanahrte et al. 2012; Zittis 2018).

\section{Definition of seasons, sub-periods, and sub-regions}

Projected changes are presented for different times-scales and future periods. Following IPCC's AR5 (IPCC 2013a), the years 1986-2005 are defined as our recent past reference period, while the time-slices 2046-2065 and 2081-2100 are representative for the mid and end of the twenty-first century. This selection facilitates a direct comparison of our findings with the latest IPCC reports. For precipitation and mean temperature, annual sums and averages were calculated respectively. Additionally, boreal summer (June-July-August) maximum temperatures and winter (December-JanuaryFebruary) minimum temperatures were included in the analysis in order to explore changes in a seasonal context. For precipitation, the year was divided in the wet and dry seasons representative for the Mediterranean. The former includes the 6-month period October to March, while the latter the period April to September.

Annual time-series of precipitation and temperature were calculated over four sub-regions covering the northwest 
(N.W.), northeast (N.E.), southeast (S.E.), and southwest (S.W.) parts of Mediterranean. The boundaries of these subregions are defined in Fig. S1 (top left panel). Data from EURO-CORDEX and MED-CORDEX experiments only were used for the construction of the time-series of the two northern sub-domains. Only CORDEX-AFRICA and MENA-CORDEX simulations provided data for the timeseries of the two southern sub-domains. For all cases, landonly grid points were analyzed.

\section{Robustness and significance}

The degree of agreement between the model simulations is assessed by using the robustness measure $R$ as introduced by Knutti and Sedlacek (2013). It is defined as $R=1-A 1 / A 2$, where $A l$ is defined as the integral of the squared area between two cumulative density functions characterizing the individual model projections and the multi-model mean projection and $A 2$ is the integral of the squared area between two cumulative density functions characterizing the multi-model projection and the historical climate. A value of $R$ equal to one implies perfect model agreement, near-zero values indicate that the model spread is comparable to the climate change signal, while negative $R$ values indicate that the model spread is much larger than the signal of changes. For this study, $R$ values equal or greater than 0.8 are considered to indicate a good agreement (i.e., high robustness) between the members of the ensemble set.

The significance of the projected changes of climatic variables is defined in a similar way as in IPCC's Atlas of Global and Regional Climate Projections (IPCC 2013b). For a particular future period, a change is considered significant when its signal is larger than the interannual variability of the control historical period. Interannual variability is straightforwardly derived from the calculation of the standard deviation for temperature, while for precipitation, the coefficient of variation (i.e., the standard deviation divided by the mean) was additionally considered.

\section{Changes in interannual variability}

The effects of global warming may not be limited to changes in long-term mean climate properties. Changes in the interannual variability of several meteorological variables can also play a crucial role for natural ecosystems as well as human activities (with consequences, e.g., for agriculture, water, and energy management etc.). In this context, we present the percentage changes of interannual variability for all variables presented in the previous sections. This metric is defined by one standard deviation calculated for annual and seasonal temperature and precipitation time-series. Changes for two future periods (MID 2046-2065 and END 2081-2100 of twenty-first century) are calculated with respect to the reference historical period. These fractional changes of interannual variability are classified similarly to Giorgi (2006). That study concluded that changes in the occurrence of extreme events closely follow the changes in interannual variability. Therefore, such changes can be also considered as a proxy measure of seasonal weather extremes. For precipitation, in addition to the standard deviation, we assessed changes in the coefficient of variation, sometimes described as the relative standard deviation (Deitch et al. 2017). This metric is often used as a proxy of the standard deviation since it removes the dependency of the precipitation standard deviation on the mean (Giorgi 2006). Nevertheless, both the coefficient of variation and standard deviation are commonly applied in this type of assessments since they can provide complementary insights into the effect of climate change on interannual variability (Räisänen 2002; Pendergrass et al. 2017 and references therein).

\section{Timing of 1.5 and $2{ }^{\circ} \mathrm{C}$ regional warming}

As a final analysis step, we investigate when the Mediterranean regional warming will reach the 1.5 and 2 ${ }^{\circ} \mathrm{C}$ levels that are often considered critical thresholds for the impact in human and natural ecosystems (IPCC 2018). Timing of global warming levels (GWLs) are often defined based on a combination of the observed global temperature rise since pre-industrial to present and the GCMprojected future warming relative to present (Dosio and Fischer 2018; Kjellström et al. 2018; Nikulin et al. 2018). We apply a similar approach to define regional warming levels (RWLs) by combining the observed regional warming and future RCM-based projections. Here, we consider an observed Mediterranean warming of $0.8{ }^{\circ} \mathrm{C}$ since pre-industrial (1880-1899) to present conditions (1986-2005) based on Cramer et al. (2018). Time-series of anomalies are calculated for the whole Mediterranean $\left(9.25^{\circ} \mathrm{W}\right.$ to $40.75^{\circ} \mathrm{E}, 26.75^{\circ} \mathrm{N}$ to $46.25^{\circ} \mathrm{N}$, including land and ocean) while the emergence years for reaching the 1.5 and $2{ }^{\circ} \mathrm{C}$ RWLs are determined by the year when the 5-year, 15-year, and 30-year running means cross these temperature thresholds (Vautard et al. 2014). Timeseries are calculated for the ensemble mean of the CORDEX simulations. As a reference for comparison, we also provide the global time-series of the CMIP5 ensemble mean based on the models used to drive the CORDEX simulations analyzed in the present study. Since in our GCM/RCM matrix the global models may appear more than once, we have applied a weighting (no. of times GCM used divided by the total number of GCM/ RCM pairs) in order to have comparable results between the GCM and RCM time-series. 


\section{Results}

\section{Model validation and inter-domain comparison}

A detailed comparison between the CRU gridded observations and our CORDEX ensemble is presented in Section S1 of the Supplementary Material. This analysis indicates a good agreement in the spatial distribution of both temperature and precipitation. Nevertheless, local biases exist with most pronounced an underestimation of temperature over the Sahara and parts of Middle East throughout the year and an overestimation of winter precipitation over southern Europe and northern parts of the Mediterranean (Figs. S1-S3).

For the EURO-CORDEX and CORDEX-AFRICA simulations, for which most of the GCM/RCM combinations are common, we investigated the effects of the domain placement (Figs. S5-S9 of the supplementary material). This analysis was based on data for the 1986-2005 reference period, while the CRU observations were used as reference.

Firstly, for 18 common GCM/RCM runs, we present boxplots of the mean absolute error for annual precipitation and temperature and for the overlap region of EUROCORDEX and CORDEX-AFRICA domains (blue-shaded area in Figs. S5 and S6). The spread of the boxplot represents all grid points of this overlap region. Figures S5 and S6 indicate that for some sets of GCMs/RCMs, the EURO-CORDEX domain is on average slightly more accurate in simulating this region. However, some other simulations indicate the opposite, while there is no specific or systematic pattern discernable. For example, the EC-EARTH/RCA4 absolute temperature bias is on average lower for the CORDEX-AFRICA domain while the precipitation bias is on average lower for EUROCORDEX domain. Similarly, no specific pattern or conclusion can be derived for a particular GCM or RCM.

Maps presenting the difference between the mean absolute error for each domain were also constructed. An indicative selection of these maps is presented in Figs. S7 and S8 for annual temperature and precipitation. Blue colors indicate regions where CORDEX-AFRICA simulations outperform the EURO-CORDEX ones (i.e., smaller mean absolute error), while the opposite is indicated by red colors. Consistent with the boxplot analysis, systematic differences are not evident and no conclusions can be derived towards any specific model configuration. For different sets of GCMs/RCMs and variables under consideration, no specific domain is found to be most appropriate.

A third aspect was investigated by comparing monthly precipitation and temperature averaged over the overlap region, all common GCM/RCM combinations and for the whole 1986-2005 reference period (Fig. S9). Similar to the previous two comparisons, there are months that are better reproduced by simulations over one of the two domains, while others are not, and there are also no consistent biases between them for temperature and precipitation.

The uncertainty related to the domain selection can partly be attributed to the sensitivity of RCM results to the variable boundary conditions provided by the GCMs. Moreover, some synoptic scale processes that affect the selected regions can overlap with the areas outside the CORDEX domains which unavoidably have to be limited in spatial extent. The Mediterranean is also characterized by strong horizontal (mostly north-south) climate gradients and diverse precipitation regimes, and therefore parameterization schemes that are developed or tuned for a specific regime may not have the same skill throughout the domain. As a result, some of the tested models may treat the regional processes that control Mediterranean climate differently depending on the placement of the integration domain as well as model configuration. For this reason, the large ensemble is expected to provide useful information with respect to spurious variability from RCMspecific geographies and we find more appropriate to include information from different domains when this is available. This sensitivity of the simulated climate to the CORDEX domain selection for an overlapping region could be more thoroughly investigated in future studies.

\section{Annual temperature projections}

Projected changes for mean annual temperature (relative to the reference period 1986-2005) are presented in Fig. 2 for two future periods and three RCP scenarios. Significance (upward hatching) and robustness (downward hatching) are also indicated. According to the ensemble mean of all RCP2.6 simulations, near-surface temperature of the broader Mediterranean region is projected to increase $0.5-2{ }^{\circ} \mathrm{C}$ by mid twenty-first century. The low robustness indicates a model spread comparable to the climate change signal.

Based on RCP2.6 and by the end of the century, the projected warming is found to diminish, as a result of the reduced GHG concentrations proposed by this scenario. According to our definition of significance, for most of the region, temperature changes are found to be significant for both time slices. This is due to the fact that even this relatively moderate warming is still greater than the historical interannual variability of annual temperature as the models suggest for the particular scenario (see also Fig. 3). For the "business-as-usual" RCP8.5, the projected changes are much more pronounced. CORDEX models suggest a warming of up to $3.5-4{ }^{\circ} \mathrm{C}$ for the period 2046-2065. By the end of the twenty-first century, the warming will likely intensify and exceed $3.5-5.5{ }^{\circ} \mathrm{C}$ in most locations. This is more pronounced over the southern parts of the region of interest. Future projections forced under the intermediate RCP4.5 lie somewhere in between. The end-century RCP4.5 pattern is very similar 
Fig. 2 Projected changes of mean annual temperature for mid (MID 2046-2065) and end (END 20812100) of twenty-first century with respect to the reference period (CTL 1986-2005), for three RCP pathways (RCP2.6: top row, RCP4.5: middle row and RCP8.5: bottom row). Robustness and significance are indicated
2-M TEMPERATURE CHANGE MID-CTL (RCP2.6)

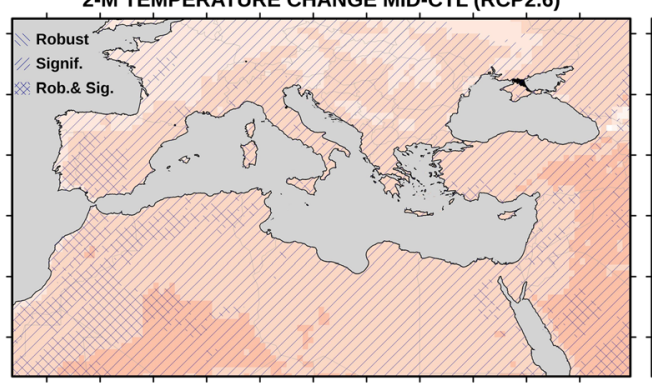

2-M TEMPERATURE CHANGE MID-CTL (RCP4.5)

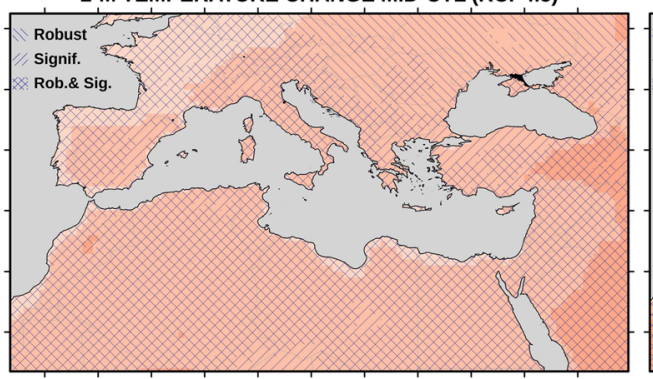

2-M TEMPERATURE CHANGE MID-CTL (RCP8.5)

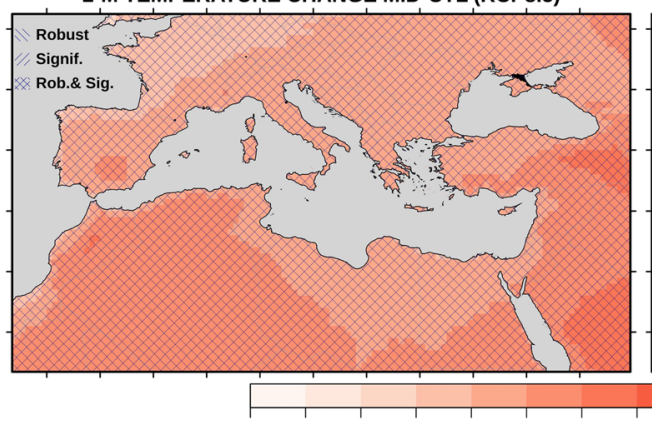

2-M TEMPERATURE CHANGE END-CTL (RCP2.6)

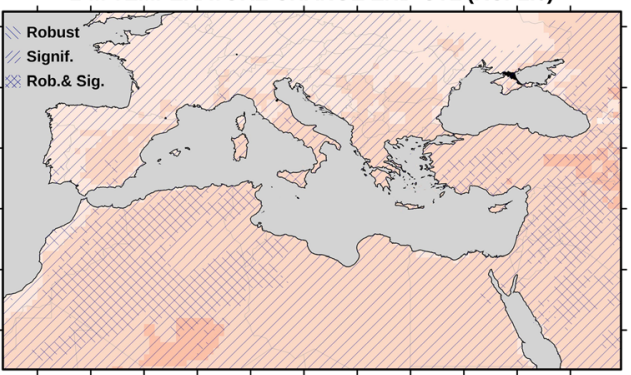

2-M TEMPERATURE CHANGE END-CTL (RCP4.5)

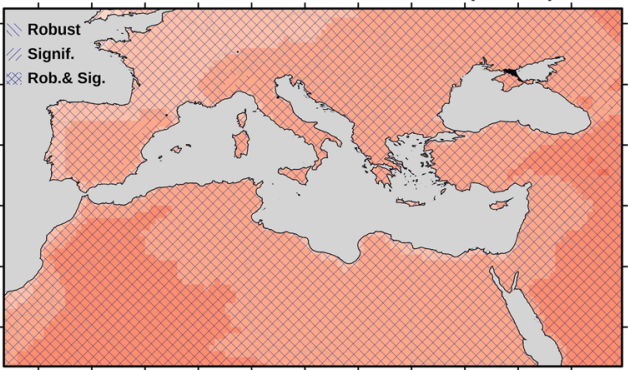

2-M TEMPERATURE CHANGE END-CTL (RCP8.5)

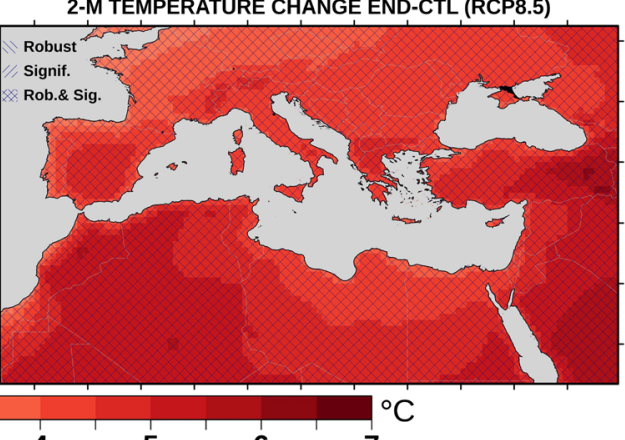

(in magnitude and spatial variation) to the mid-century RCP8.5, highlighting the importance of the choice of the pathway in the timing of the expected temperature impact. Interestingly, the climate change signal of annual mean temperature is significant and robust for both RCP4.5 and RCP8.5 pathways and for both future time slices. For these two pathways, changes are larger than two times the standard deviation of the reference period (not shown).

The time-series of Fig. 3 represents the annual temperature anomalies with respect to the mean of the 19862005 reference period. These are calculated for the four Mediterranean sub-regions defined in "Definition of seasons, sub-periods and sub-regions." Following the forcing pathways, the climate projections start to diverge after the 2030s-2040s. Pathway RCP8.5 suggests an almost linear temperature increase for the twenty-first century. For the simulations forced by the intermediate RCP4.5, the rate of warming slows down after the 2050s, while under the more optimistic RCP2.6, a slight negative trend is suggested after the 2050s. Also, since fewer simulations were available for RCP2.6, the box plots of Fig. 3 indicate a much smaller model spread. According to the ensemble mean of CORDEX simulations, the warming will likely be most pronounced in S.W. Mediterranean.

\section{Seasonal temperature projections}

Projected changes for summer maximum temperature are presented in Fig. S10 of the supplementary material. For all RCPs, the summer warming is found to be much more pronounced in comparison to annual temperature changes. Even though the RCP2.6 pathway implies an average global warming of near $2{ }^{\circ} \mathrm{C}$ by the end of the century, for parts of the Mediterranean, summers are expected to well exceed this threshold. In agreement with the annual mean temperature projections, the warming is less, towards the end of the twenty-first century, while these changes are significant only for southern regions and robust mainly for the Middle East part of the Mediterranean. For RCPs 4.5 and 8.5, the future summer warming is locally expected to reach $4.5^{\circ} \mathrm{C}$ and $7{ }^{\circ} \mathrm{C}$, respectively, by the end of the century. In the latter case, societally destabilizing conditions may be induced since summer temperatures over parts of the region (e.g., in Middle East and 


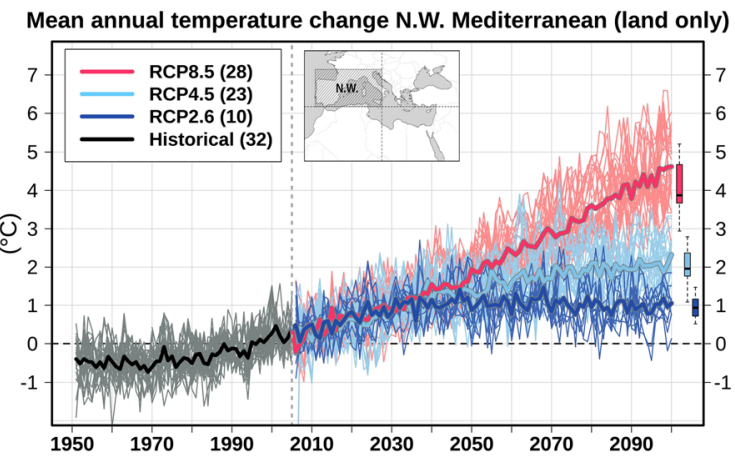

Mean annual temperature change N.E. Mediterranean (land only)
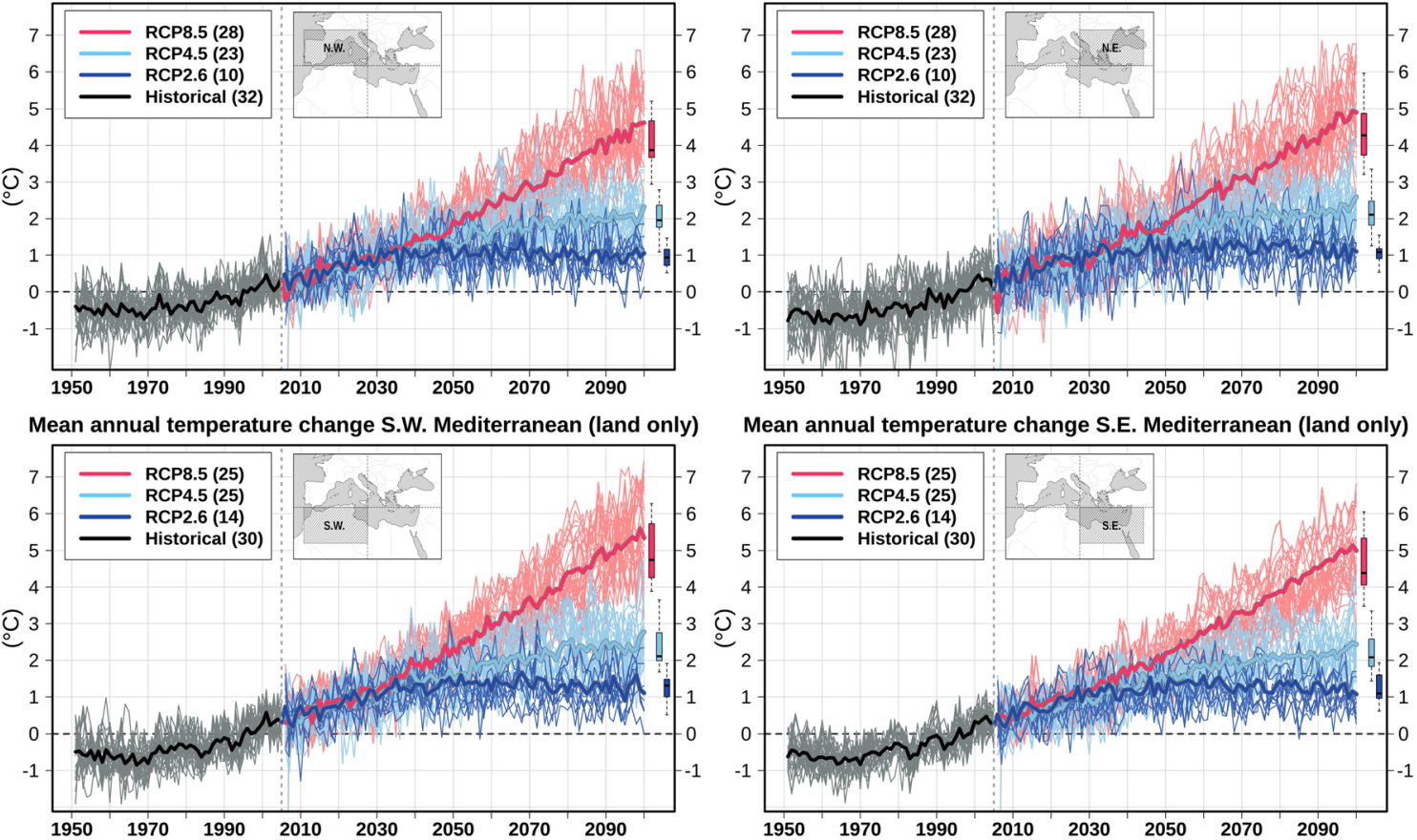

Mean annual temperature change S.E. Mediterranean (land only)

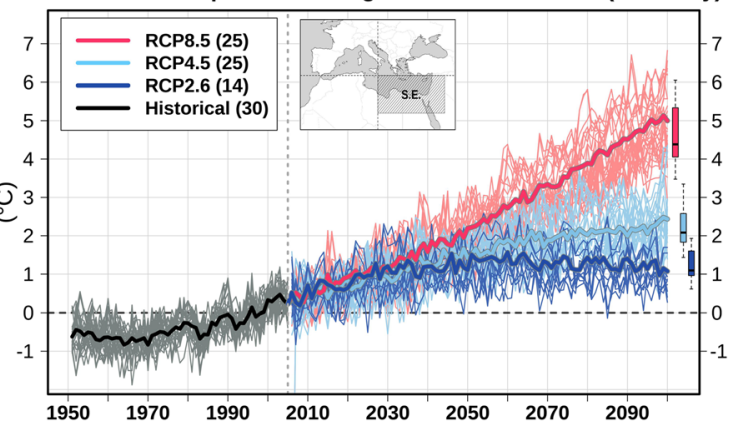

Fig. 3 Projected time-series of annual mean temperature anomalies with respect to the reference period 1986-2005, for the historical and three RCP simulations (RCP2.6, RCP4.5, and RCP8.5), for the four Mediterranean sub-regions. Thin lines denote individual ensemble members and thick lines the CORDEX multi-model mean. Box plots indicate

the minimum, 25th, 50th (median), 75th percentiles of the ensemble set distribution of 20-year mean anomalies (2081-2100). Vertical dashed lines indicate the last year (2005) of the historical simulation data. The sub-region is indicated in the title of each plot and depicted in the respective quadrant.

north Africa) are already very high (Lelieveld et al. 2016; Pal and Eltahir 2016). For both scenarios, changes are significant since they exceed the historical interannual variability range. Robustness is generally high, particularly for RCP8.5 and the 2081-2100 future period. According to RCP4.5 and RCP8.5 simulations, summer maximum temperature warming will be intensified over regions that will likely experience a strong drying (see the following section). Such regions include parts of Maghreb, Iberia, Alps, Italy, Balkans, and the Anatolian Plateau. There, land-atmosphere interactions and the effect of decreased soil moisture and evapotranspiration, induced by the projected rainfall decrease, can accelerate the warming (Zittis et al. 2014 and references therein).

In comparison with summer maximum and annual temperature, the warming of winter minimum temperature is less pronounced for most sub-regions along the Mediterranean coast (Fig. S11). Interestingly, this is not the case for the northeastern part of our domain where winter warming is found to be stronger. Snow-albedo feedback (Winter et al. 2017) is likely contributing to this outcome since in a warmer future, smaller areas are expected to be covered by snow during winter and for shorter periods. Winter warming is characterized by low levels of significance and robustness for scenario RCP2.6, while the climate change signal is limited to an additional $0.5-1.5{ }^{\circ} \mathrm{C}$ to the $1986-2005$ average. In contrast, winter temperature changes are projected to be both robust

and significant for the end of the century under pathways RCP4.5 and RCP8.5. For the former scenario, changes range between 2 and $4{ }^{\circ} \mathrm{C}$, while for the latter, winter warming ranges between 3 and $6{ }^{\circ} \mathrm{C}$. Additional hot spots for winter warming are snow-covered regions such as the Alps and Armenian Highlands, suggesting that the snow-albedo feedback explains these warming peaks. A winter warming hot spot is also suggested for the southern boundaries of our Mediterranean domain. This pattern could potentially be related to changes and displacement of the Hadley Cell circulation that needs further investigation.

The patterns and magnitude of seasonal warming are generally consistent with studies based on global models (IPCC 2013b; Lelieveld et al. 2016; Lionello and Scarascia 2018). However, the strong summer warming by the end of the twenty-first century appears less profound in IPCC's Atlas of Global and Regional Climate Projections. In the latter report, where only RCP4.5 results are presented, winter and summer warming are found to be more uniform.

\section{Annual precipitation projections}

Although the CORDEX ensemble suggests an overall drying for most of the Mediterranean Basin, these changes are found to be neither significant nor robust according to our definitions (Fig. 4). One exception is a strong drying signal for pathway 
Fig. 4 Same as Fig. 2 for annual precipitation changes
PRECIPITATION CHANGE MID-CTL (RCP2.6)

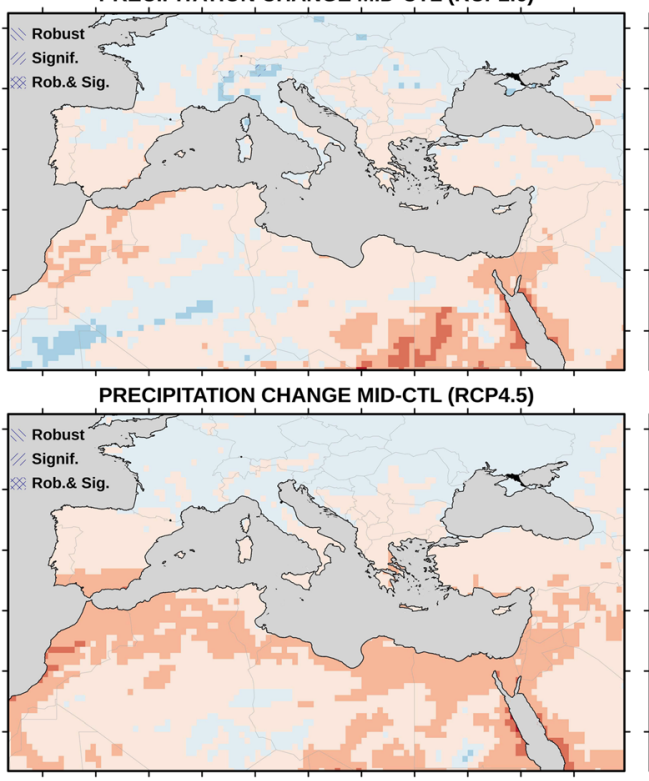

PRECIPITATION CHANGE MID-CTL (RCP8.5)
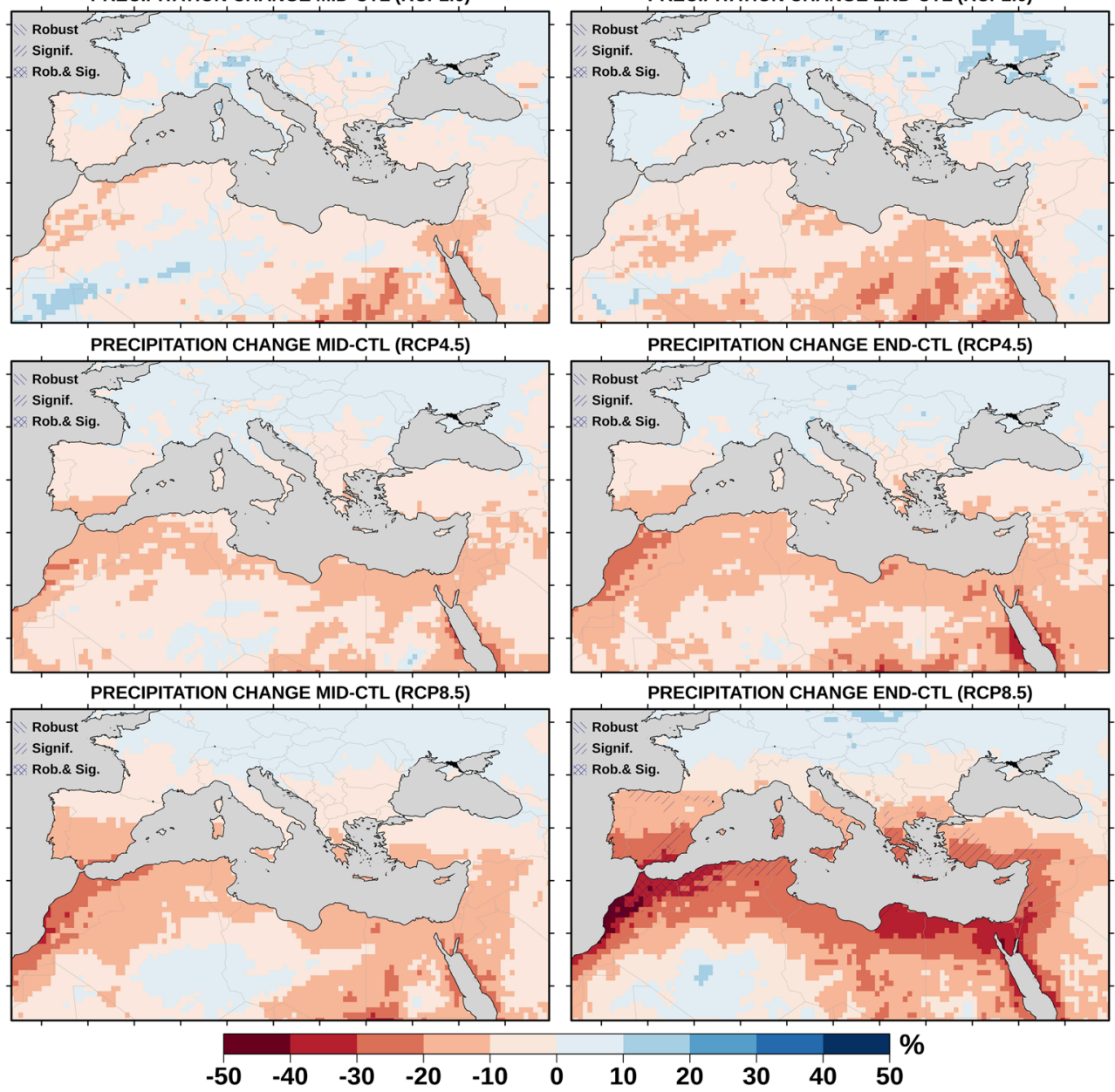

PRECIPITATION CHANGE END-CTL (RCP4.5)

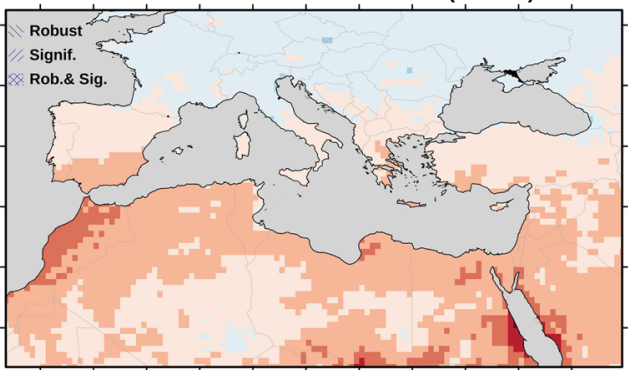

PRECIPITATION CHANGE END-CTL (RCP8.5)

PRECIPITATION CHANGE END-CTL (RCP2.6)

\section{.

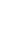

RCP8.5 and towards the end of the century. According to the ensemble mean of the CORDEX simulations, this significant drying is affecting most of the Mediterranean coast and particularly Iberia, parts of Maghreb, southern Italy, Balkans, southern Turkey, and the Levantine. It is projected to reach - $30 \%$, while for some parts of southern Mediterranean, the rainfall decrease will reach or exceed $-40 \%$ of annual precipitation of the reference period, if this scenario becomes a reality. For southern Europe and the Mediterranean, our results are qualitatively and quantitatively in good agreement with a high-resolution EURO-CORDEX ensemble study (Jacob et al. 2014). In that study, precipitation changes were found to be both significant and robust; however, the authors used different definitions for these two metrics.

For the northern boundaries of our domain and extended regions in central and east Europe, CORDEX models suggest a precipitation increase of about $10 \%$, which is however not significant since it is found to be within the range of the natural interannual variability of the reference period. This agrees with many modeling studies with a global or European focus (e.g., Jacob et al. 2014) and can be explained by changes in water-holding capacity of the atmosphere, governed by the
Clausius-Clapeyron equation (Trenberth et al. 2003), combined with a poleward shift of wintertime mid-latitude storm tracks (Ulbrich et al. 2009; Lelieveld et al. 2012; Lehmann et al. 2014). Notwithstanding the absence of robustness or significance, there is an increasing north to south gradient towards drier conditions from RCP2.6 to RCP8.5 and from mid to end century.

The time-series of precipitation anomalies (with respect to 1986-2005 means) indicate much larger interannual variability for the southern part of the Mediterranean, which is evident for both the historical and future scenario simulations (Fig. 5). A stronger drying over this part of the basin is also suggested by the CORDEX simulations. There are models that suggest up to $-60 \%$ precipitation decrease for RCP8.5 by the end of the twenty-first century. On average, the more moderate RCP2.6 scenario indicates a much smaller drying (5-10\%) in the southern Mediterranean, while for the northern parts, a weak precipitation increase is suggested (related to the northward migration of storm tracks); however, again, the signal is much smaller than the natural interannual variability. Intermediate scenario RCP4.5 suggests a drying for all subregions. In terms of percentage decrease, it is expected to 
Annual precipitation change N.W. Mediterranean (land only)

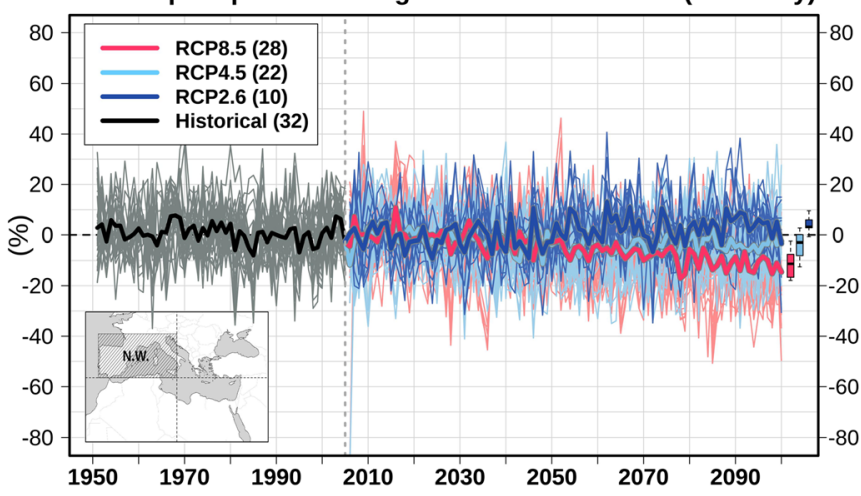

Annual precipitation change S.W. Mediterranean (land only)

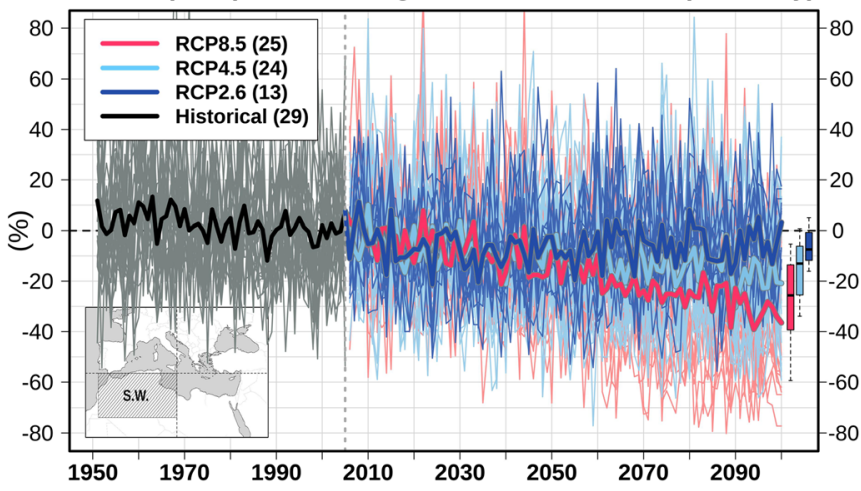

Fig. 5 Same as Fig. 3 for annual precipitation anomalies

reach $20 \%$ for southern Mediterranean where stronger drying is suggested.

\section{Seasonal precipitation projections}

Changes in precipitation during the wet half of the year are presented in Fig. S12. As is the case for annual precipitation, robustness and significance levels are generally low. CORDEX projections indicate a change in different directions for the northern and southern parts of Mediterranean. For the southern Mediterranean, strong decreases of precipitation are projected. These estimates are amplified towards the end of the century and also for the transition towards pathways RCP4.5 and RCP8.5. For the business-as-usual scenario (RCP8.5), wet season precipitation decrease will likely exceed $30-40 \%$ in the southern Mediterranean area and Europe's southernmost regions. This signal is locally found to be significant and robust. The winter-time decrease of precipitation under climate change conditions can be attributed to changes in atmospheric circulation and a poleward shift of the midlatitude westerly zonal winds and associated storm tracks (Zappa et al. 2015; Shaw et al. 2016). This results in the wetting of the northernmost part of our domain which is becoming stronger in the CORDEX simulations towards the end of the twenty-first century, and under the stronger radiative forcing scenarios. These precipitation increases (up to $10-$
Annual precipitation change N.E. Mediterranean (land only)

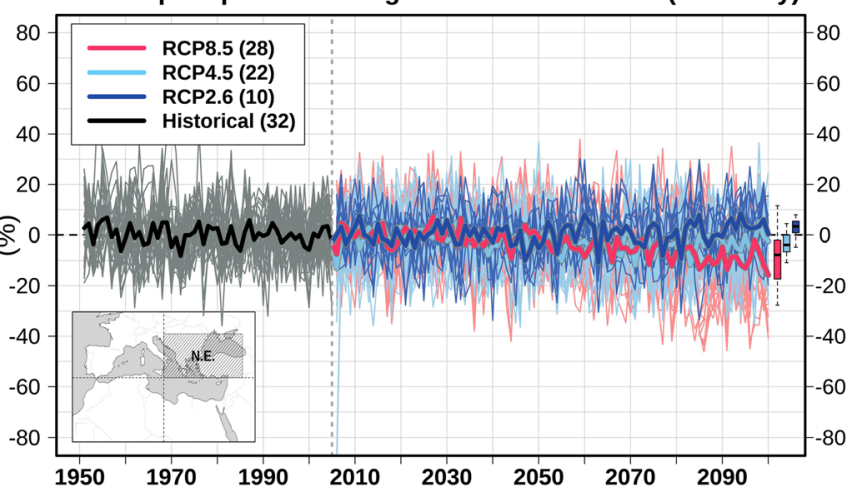

Annual precipitation change S.E. Mediterranean (land only)

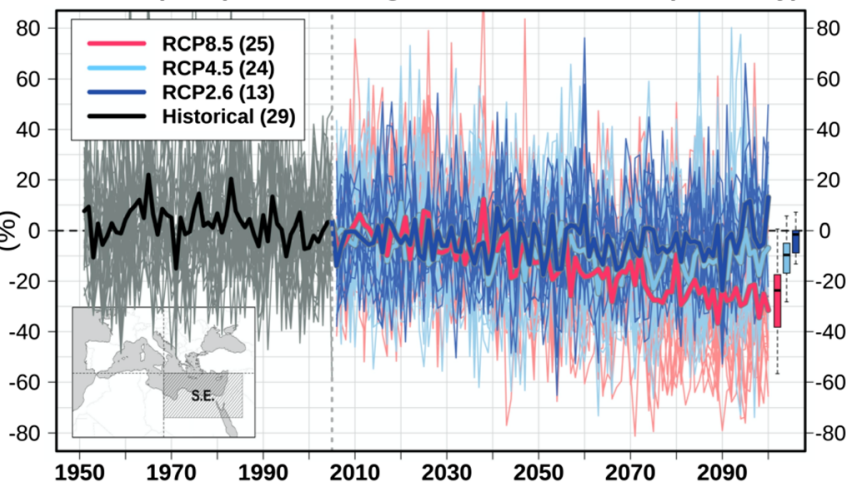

$20 \%$ ) are locally found to be significant as they are higher than the natural interannual variability of the historical reference period. They could potentially have important consequences such as torrential rains and flooding associated with extreme events. Although these regions are not directly Mediterranean, winter season precipitation increases could affect the hydrological cycle further downstream of rivers that influence the basin.

During the dry part of the year, the pattern of changes is different (Fig. S13). Over the already arid southern Mediterranean, the summer drying is projected to be much smaller in comparison with the wet season. Further, the models suggest an increase in summer precipitation in some regions located in the southern parts of the domain. These increases however are very small in actual rainfall amount and could potentially be explained by the northward displacement of the inter-tropical convergence zone during this season (Evans 2010). Conversely, southern Europe and the northern Mediterranean are expected to experience stronger precipitation reductions in the dry season. This drying becomes more pronounced for the end of the century and RCPs 4.5 and 8.5. Particularly for RCP8.5, this change is significant for parts of the Iberian Peninsula, southern France, Italy, western Greece, and central/northern Turkey. According to climate models, there is a strong effect of global warming on sea level pressure that is apparently controlling the summer drying. As future 
climate projections suggest, an intensification of the Azores anticyclone could lead to a reduction of weather regimes producing precipitation events in the northern part of the basin during summer (Lionello and Scarascia 2018). The summer drying over the eastern part of the Mediterranean could also be augmented by increasing subsidence due to the influence of South Asian Monsoon in the eastern Mediterranean summer circulation, a dynamical feedback that is evident in the present (Tyrlis et al. 2013) and could change in the future.

The patterns of seasonal precipitation changes agree and complement previous studies based on global climate models (e.g., Lelieveld et al. (2016). Although the IPCC Atlas of Global and Regional Climate Projections (IPCC 2013b) provides much coarser resolution information, the magnitude of changes and their significance level is generally in agreement with the CORDEX simulations presented here. The differential climate responses of the northern and southern Mediterranean and the northward (southward) displacement of the strong drying zone during the dry (wet) season were also highlighted in Lionello and Scarascia (2018). This feature is likely related to a seasonally dependent poleward expansion of the northern hemisphere Hadley Cell descending branch (Kang and Lu 2012).

\section{Changes in interannual variability}

Interestingly, for near-surface temperature, CORDEX simulations suggest a tendency for decreased interannual variability under pathway RCP2.6 (Table 1). This decrease is stronger for the southern Mediterranean and during the summer season and could be an indication of fewer seasonal temperature extremes in future. This highlights the additional benefits of the implementation of such a pathway and aggressive mitigation options. Changes in annual and seasonal temperature interannual variability for RCP4.5 simulations are found to be less profound. Conversely, the business-as-usual RCP8.5 scenario indicates an increase of temperature interannual variability for all sub-regions and seasons under investigation. This could be an indication of the increased occurrence of hot weather events. An exception is the minimum temperature in the northern Mediterranean region, where decreased temperature variability is projected, likely contributing to a decrease in cold spells.

Regarding precipitation variability in absolute terms (standard deviation), the impacts can be different for the northern and southern Mediterranean climate regimes. For the northern part, interannual variability is projected to increase under all pathways. This is becoming more evident towards the end of the twenty-first century. Relatively strong increases of the interannual rainfall standard deviation are projected for the wet season, which could be critical for ecosystems, agriculture, and surface and underground water resources. Besides the overall drying trends, such increases in the interannual variability for the northern Mediterranean could drive seasonal or multiannual droughts or on the other hand favor preconditions for floods during abnormally dry or wet periods, respectively. For the southern Mediterranean, interannual variability of precipitation is projected to decrease during all seasons.

Projected changes of the relative standard deviation or coefficient of variation mostly indicate strong increases which are most pronounced towards the end of the $21 \mathrm{st}$ century and under pathway RCP8.5. This is related to the fact that the mean annual/seasonal precipitation is projected to change more strongly than the respective changes of standard deviation, leading to higher future coefficients of variation. This is an indication of increasing relative extremes (extreme wet or dry seasons) in a future climate that could potentially affect the adaptive capacity of humans and natural ecosystems.

\section{Timing of 1.5 and $2{ }^{\circ} \mathrm{C}$ regional vs. global warming}

The ensemble mean of CORDEX simulations is in good agreement with the observed trends (Cramer et al. 2018) and corroborates that the Mediterranean is already entering the $1.5{ }^{\circ} \mathrm{C}$ climate warming era (Fig. 6-left panel). The simulated years of emergence of the $1.5{ }^{\circ} \mathrm{C}$ regional warming level are an indication that we are currently more on the track of the RCP 8.5 pathway in terms of GHG concentrations and emissions. The regional warming since pre-industrial is projected to reach the $2{ }^{\circ} \mathrm{C}$ well within two decades, unless strong GHG concentration reductions are implemented. According to this CORDEX "super-ensemble," for the running century, the $2{ }^{\circ} \mathrm{C}$ climate warming in the region cannot be avoided under any of the investigated scenarios. The fact that under pathway RCP2.6 the Mediterranean is expected to reach the 1.5 ${ }^{\circ} \mathrm{C}$ warming level faster than RCP4.5 is consistent with the GHG concentrations considered under this "optimistic" scenario that apparently for the near future are projected to be higher than projections under RCP4.5 (Riahi et al. 2007).

The right panel of Fig. 6 depicts a similar analysis based on the output of the global CMIP5 models that were used to drive the CORDEX RCMs analyzed in this study. A comparison with the Mediterranean analysis indicates that the region is indeed expected to warm at a faster rate than the global average. For the end of the twenty-first century, the Mediterranean is projected to experience an additional warming of up to 0.5 ${ }^{\circ} \mathrm{C}$. According to the CMIP5 models, the global warming levels of 1.5 and $2{ }^{\circ} \mathrm{C}$ will be reached later than what the CORDEX simulations suggest for the Mediterranean. Noteworthy, the $2{ }^{\circ} \mathrm{C}$ threshold for global mean temperature 
Table 1 Percentage change of interannual variability ( $\Delta$ var), expressed as difference of the 20-year standard deviation for mid (MID 2046-2065) and end (END 2081-2100) of twenty-first century with respect to the reference historical period (CTL 1986-2005), under three future RCP pathways for temperature (TAS) and precipitation (PR). Negative (positive) values are highlighted in blue (red). For precipitation, the percentage change of the coefficient of variation is also presented

\begin{tabular}{|c|c|c|c|c|c|c|c|c|}
\hline Metric & Variable & Sub-region & RCP2.6 MID & RCP2.6 END & RCP4.5 MID & RCP4.5 END & RCP8.5 MID & RCP8.5 END \\
\hline \multirow{12}{*}{ 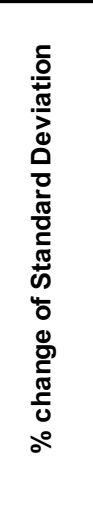 } & \multirow{4}{*}{$\begin{array}{c}\text { TAS } \\
\text { (ANNUAL) }\end{array}$} & NW Med. & 6.1 & 10.2 & 0.0 & -3.6 & 12.7 & 18.2 \\
\hline & & NE Med. & -7.6 & -10.6 & -7.5 & -1.5 & 8.8 & 5.9 \\
\hline & & SE Med. & -14.0 & -18.0 & -4.0 & -12.0 & 16.0 & 14.0 \\
\hline & & SW Med. & -17.5 & -19.3 & -3.5 & -1.8 & 10.5 & 15.8 \\
\hline & \multirow{4}{*}{$\begin{array}{l}\text { TASMIN } \\
\text { (DJF) }\end{array}$} & NW Med. & 2.1 & -2.1 & -6.1 & -3.1 & -3.1 & -6.1 \\
\hline & & NE Med. & -2.1 & -7.9 & -10.6 & -7.0 & -8.5 & -14.9 \\
\hline & & SE Med. & 2.6 & -7.7 & 2.6 & 1.3 & 13.0 & 15.6 \\
\hline & & SW Med. & -2.2 & -8.8 & 0.0 & 3.4 & 7.9 & 7.9 \\
\hline & \multirow{4}{*}{$\begin{array}{c}\text { TASMAX } \\
\text { (JJA) }\end{array}$} & NW Med. & 0.8 & 7.4 & 1.6 & 2.4 & 0.8 & 5.7 \\
\hline & & NE Med. & -1.6 & -11.4 & 1.6 & -0.8 & 1.6 & 4.8 \\
\hline & & SE Med. & -17.7 & -12.7 & -3.8 & -8.8 & 6.3 & 5.1 \\
\hline & & SW Med. & -13.0 & -5.4 & -5.2 & -10.3 & 2.1 & 1.0 \\
\hline \multirow{12}{*}{ 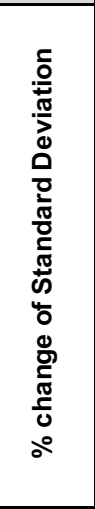 } & \multirow{4}{*}{$\begin{array}{c}\text { PR } \\
\text { (ANNUAL) }\end{array}$} & NW Med. & 3.5 & 0.4 & -0.9 & 3.5 & 0.7 & 1.8 \\
\hline & & NE Med. & 3.8 & 7.4 & 6.6 & 10.8 & 3.5 & 7.8 \\
\hline & & SE Med. & -3.5 & -2.1 & -5.5 & -4.3 & -5.3 & -10.6 \\
\hline & & SW Med. & -0.5 & -7.3 & -3.6 & -2.0 & -4.9 & -7.4 \\
\hline & \multirow{4}{*}{ PR (WET) } & NW Med. & 6.0 & 4.2 & 3.5 & 12.3 & 2.3 & 6.7 \\
\hline & & NE Med. & 4.1 & 7.7 & 9.9 & 15.5 & 7.4 & 11.7 \\
\hline & & SE Med. & 0.3 & 1.9 & -3.5 & -2.2 & -2.2 & -7.2 \\
\hline & & SW Med. & 1.6 & -7.0 & -3.2 & 0.6 & -10.9 & -15.2 \\
\hline & \multirow{4}{*}{ PR (DRY) } & NW Med. & 2.2 & 2.3 & 0.4 & 2.4 & -7.1 & -7.1 \\
\hline & & NE Med. & -0.3 & 1.4 & 2.6 & 6.0 & -4.2 & -3.0 \\
\hline & & SE Med. & -8.0 & -11.9 & -5.4 & -9.1 & -6.8 & -15.3 \\
\hline & & SW Med. & -3.7 & -4.6 & -1.7 & -4.3 & -1.2 & -6.4 \\
\hline \multirow{12}{*}{ 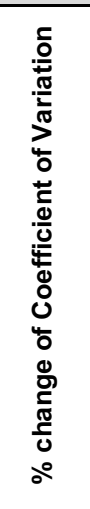 } & \multirow{4}{*}{$\begin{array}{c}\text { PR } \\
\text { (ANNUAL) }\end{array}$} & NW Med. & 3.2 & -2.6 & 2.9 & 5.6 & 10.5 & 20.0 \\
\hline & & NE Med. & 3.0 & 4.7 & 8.2 & 11.6 & 7.0 & 21.6 \\
\hline & & SE Med. & 1.6 & 1.4 & 6.9 & 12.8 & 10.6 & 21.9 \\
\hline & & SW Med. & 6.5 & 3.7 & 11.1 & 15.5 & 17.2 & 33.0 \\
\hline & \multirow{4}{*}{ PR (WET) } & NW Med. & 1.2 & -1.4 & 0.5 & 5.4 & 5.9 & 13.2 \\
\hline & & NE Med. & 1.6 & 2.9 & 6.3 & 9.0 & 7.6 & 17.3 \\
\hline & & SE Med. & 7.3 & 2.9 & 5.7 & 15.8 & 14.3 & 23.1 \\
\hline & & SW Med. & 10.6 & 8.5 & 17.4 & 20.5 & 18.5 & 38.2 \\
\hline & \multirow{4}{*}{ PR (DRY) } & NW Med. & 7.5 & 2.4 & 6.4 & 11.7 & 12.9 & 29.7 \\
\hline & & NE Med. & 3.5 & 3.6 & 5.2 & 8.9 & 8.5 & 26.5 \\
\hline & & SE Med. & 0.6 & 0.5 & 10.4 & 14.2 & 11.5 & 31.4 \\
\hline & & SW Med. & -0.1 & 0.6 & 9.1 & 16.5 & 12.9 & 29.3 \\
\hline \multicolumn{2}{|c|}{$\Delta \operatorname{var}(\%)$} & $<-15$ & {$[-15,10)$} & {$[-10,5)$} & {$[-5,5]$} & $(5,10]$ & $(10,15]$ & $>15$ \\
\hline
\end{tabular}

rise since pre-industrial times will not be reached under RCP2.6. Our findings regarding the timing of reaching the 1.5 and $2{ }^{\circ} \mathrm{C}$ RWLs cannot be directly compared to other studies, since different scenarios, number of models, or reference periods are used. Nevertheless, there are strong indications that the Mediterranean will continue to warm more strongly than the global average which is expected to reach these warming levels some years later (Vautard et al. 2014;
Dosio and Fischer 2018; Lionello and Scarascia 2018; Nikulin et al. 2018).

Besides the 5-year moving averages which are presented in the time-series of Fig. 6, the timing of reaching the warming levels of 1.5 and $2{ }^{\circ} \mathrm{C}$ was also investigated by using 15 - and 30 -year running means. However, results were found to be very similar to the ones presented in Fig. 6 since positive temperature anomalies of the years ahead the center of the 


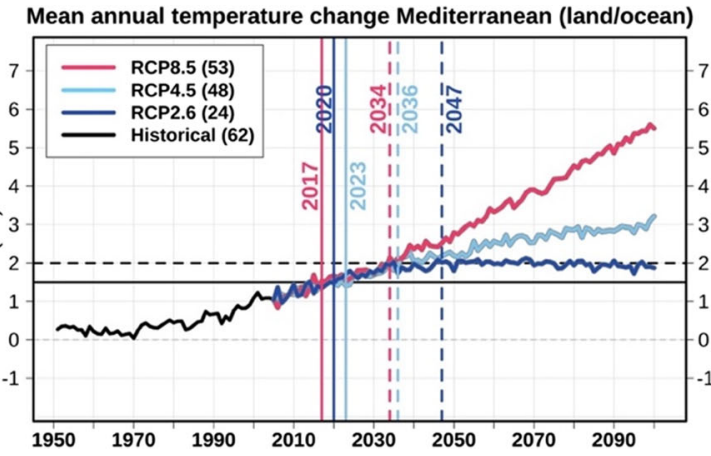

Fig. 6 Time-series of mean annual temperature anomalies since preindustrial (1880-1899) for the Mediterranean (left panel) and global averages (right panel) based on three RCP pathways. Regional and global

moving average are stronger and act as an offset, regardless the order of the moving average (not shown).

\section{Discussion and conclusions}

We present a unique collection of climate change projections, based on a multi-model, multi-domain, and multi-scenario ensemble of CORDEX simulations for the Mediterranean region. In similar previous studies, based on global models, projected changes are found to be rather uniform, as relatively small-scale climate features and feedbacks are smoothed due to the coarse resolution of GCMs. Our results could be considered as a complementary update of the IPCC Atlas of Global and Regional Climate Projections (IPCC 2013b) for the Mediterranean. In that report, only seasonal changes are presented, and maps (based on $2.5 \times 2.5^{\circ}$ data) only illustrate RCP4.5 results, while time-series represent averages over a very large domain that covers different climatic regimes and also includes a very large area of northern Africa.

We find that the vast majority of CORDEX RCMs suggests a significant temperature increase throughout the region in the twenty-first century, and we provide details for four Mediterranean sub-regions. In agreement with previous studies, the projected regional warming is found to be more pronounced in comparison with the global trends. Warming is even significant under the strong RCP2.6 mitigation pathway; however, it is more evident during the warm period of the year and for the stronger radiative forcing scenarios (RCP4.5 and RCP8.5). Societal impacts may be relatively large, since the warming combines with a general drying tendency. However, the significance levels for precipitation changes are much lower than for temperature, since precipitation is characterized by strong interannual variability, both during the historical reference period and in the future projections. Although RCMs are expected to better resolve regional processes that drive precipitation, the consistency between the models and the robustness of results are still rather low. This could partly be related to the fact that precipitation processes are still parameterized at
Mean annual temperature change Global (land/ocean)

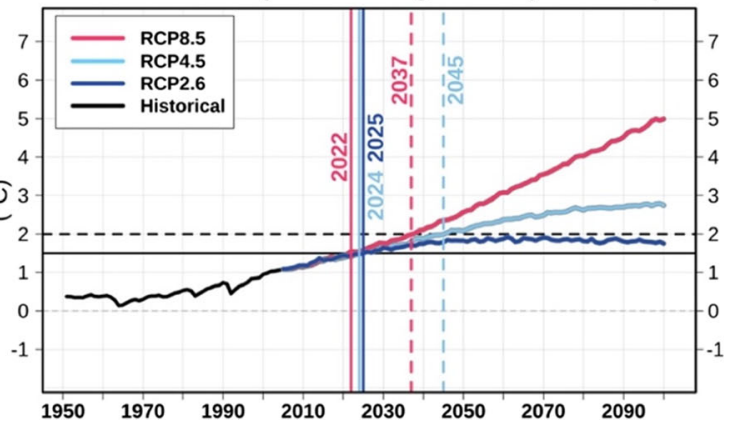

warming levels of 1.5 and $2{ }^{\circ} \mathrm{C}$ based on 5-year moving averages are highlighted by solid and dashed lines respectively

current RCM resolutions, while most models included in this study are using different types of parameterization schemes. Nevertheless, in our ensemble set, we find future precipitation trends to be of consistent sign for most models, with the exception of some outliers for RCP2.6 and RCP4.5 simulations.

Our sub-regional analysis highlights a different response to global warming for the northern and southern Mediterranean. The more vulnerable southern Mediterranean regions, with a typically lower adaptive capacity, are projected to experience strong warming, mainly in summer, combined with pronounced drying, mainly during the wet period. Northern regions are projected to experience a somewhat lower warming combined with a less pronounced precipitation decrease that will occur mainly during the driest half of the year.

Pathway RCP2.6 did not receive much attention in previous studies or references of Mediterranean climate change, since it was often considered unrealistic. However, it is the only RCP scenario that could comply with the 2015 Paris Agreement main targets, even though it may be difficult to achieve. Our synthesis of CORDEX simulations suggests that a future pathway similar to RCP2.6 could limit regional warming to levels that the region could cope with; nevertheless, it will likely imply rainfall reductions that might be critical for the arid and hyper-arid regions of southern Mediterranean.

Although changes in extreme events were not explicitly assessed here, the fact that interannual variability of temperature is projected to strongly increase throughout the Mediterranean under RCP8.5 could be an indication of increasing hot weather extremes, especially under that pathway. This is also the case for winter precipitation but only for the northern Mediterranean regions.

Current results can be considered as representative climate projections for the Mediterranean Basin, until the added value of higher-resolution and coupled RCMs become more evident and until finer-resolution CMIP6 GCMs become available for dynamical downscaling. Our results suggest that convection permitting RCMs at relatively high resolution are wanted in the future to achieve larger robustness in the projection of precipitation trends. 
Acknowledgments This research was supported by the EMME-CARE project that has received funding from the European Union's Horizon 2020 Research and Innovation Programme, under Grant Agreement No. 856612 , as well as matching co-funding by the Government of the Republic of Cyprus. This publication reflects only the authors' view. The European Community is not liable for any use that may be made for the information contained herein. We would like to thank all the CORDEX and CMIP5 modeling groups that performed simulations and publicly shared their data and particularly the MED-CORDEX, EUROCORDEX, CORDEX-AFRICA, and MENA-CORDEX communities. We would also like to acknowledge the MISTRALS and ESGF data portals for hosting these datasets.

Open Access This article is distributed under the terms of the Creative Commons Attribution 4.0 International License (http:// creativecommons.org/licenses/by/4.0/), which permits unrestricted use, distribution, and reproduction in any medium, provided you give appropriate credit to the original author(s) and the source, provide a link to the Creative Commons license, and indicate if changes were made.

\section{References}

Adloff F, Somot S, Sevault F, Jordà G, Aznar R, Déqué M, Herrmann M, Marcos M, Dubois C, Padorno E, Alvarez-Fanjul E, Gomis D (2015) Mediterranean Sea response to climate change in an ensemble of twenty first century scenarios. Clim Dyn 45(9):2775-2802. https://doi.org/10.1007/s00382-015-2507-3

Cook BI, Anchukaitis KJ, Touchan R, Meko DM, Cook ER (2016) Spatiotemporal drought variability in the Mediterranean over the last 900 years. J Geophys Res Atmos 121(5):2015JD023929+. https:// doi.org/10.1002/2015JD023929

Cramer W, Guiot J, Fader M, Garrabou J, Gattuso J-P, Iglesias A, Lange MA, Lionello P, Llasat MC, Paz S, Peñuelas J, Snoussi M, Toreti A, Tsimplis MN, Xoplaki E (2018) Climate change and interconnected risks to sustainable development in the Mediterranean. Nat Clim Chang 8(11):972-980. https://doi.org/10.1038/s41558-018-0299-2

Deitch MJ, Sapundjieff MJ, Feirer ST (2017) Characterizing precipitation variability and trends in the world's Mediterranean-climate areas. Water 9:259. https://doi.org/10.3390/w9040259

Diffenbaugh NS, Giorgi F (2012) Climate change hotspots in the CMIP5 global climate model ensemble. Clim Chang 114(3-4):813-822. https://doi.org/10.1007/s10584-012-0570-x

Diffenbaugh NS, Pal JS, Giorgi F, Gao X (2007) Heat stress intensification in the Mediterranean climate change hotspot. Geophys Res Lett 34(11):L11706+. https://doi.org/10.1029/2007GL030000

Dosio A, Fischer EM (2018) Will half a degree make a difference? robust projections of indices of mean and extreme climate in Europe under $1.5^{\circ} \mathrm{C}, 2^{\circ} \mathrm{C}$, and $3^{\circ} \mathrm{C}$ global warming. Geophys Res Lett $45(2): 935$ 944. https://doi.org/10.1002/2017GL076222

Evans J (2010) Global warming impact on the dominant precipitation processes in the Middle East. Theor Appl Climatol 99(3):389-402. https://doi.org/10.1007/s00704-009-0151-8

Flecha S, Pérez FF, García-Lafuente J et al (2015) Trends of pH decrease in the Mediterranean Sea through high frequency observational data: indication of ocean acidification in the basin. Sci Rep 5:16770. https://doi.org/10.1038/srep16770

Giorgi F (2006) Climate change hot-spots. Geophys Res Lett 33(8): L08707+. https://doi.org/10.1029/2006GL025734
Giorgi F, Gutowski WJ (2015) Regional dynamical downscaling and the CORDEX initiative. Annu Rev Environ Resour 40(1): 467-490. https://doi.org/10.1146/annurev-environ-102014-021217

Giorgi F, Gutowski WJ (2016) Coordinated experiments for projections of regional climate change. Curr Clim Chang Reports 2:202-210. https://doi.org/10.1007/s40641-016-0046-6

Giorgi F, Lionello P (2008) Climate change projections for the Mediterranean region. Glob Planet Chang 63(2):90-104. https:// doi.org/10.1016/j.gloplacha.2007.09.005

Giorgi F, Mearns LO (1999) Introduction to special section: regional climate modeling revisited. Journal of Geophysical Research: Atmospheres 104(D6):6335-6352

Giorgi F, Coppola E, Raffaele F (2014) A consistent picture of the hydroclimatic response to global warming from multiple indices: models and observations. J Geophys Res Atmos 119(20):695-708 https://doi.org/10.1002/2014JD022238

Harris I, Jones PD, Osborn TJ, Lister DH (2014) Updated high-resolution grids of monthly climatic observations - the CRU TS3.10 dataset. Int J Climatol 34(3):623-642. https://doi.org/10.1002/joc.3711

Hoerling M, Eischeid J, Perlwitz J, Quan X, Zhang T, Pegion P (2012) On the increased frequency of Mediterranean drought. J Clim 25(6): 2146-2161. https://doi.org/10.1175/JCLI-D-11-00296.1

IPCC (2013a) Climate Change 2013: The physical science basis. Contribution of Working Group I to the Fifth Assessment Report of the Intergovernmental Panel on Climate Change [Stocker TF, Qin D, et al. (eds.)]. Cambridge University Press, Cambridge and New York

IPCC (2013b) Annex I: Atlas of Global and Regional Climate Projections [van Oldenborgh GJ, Collins M, et al. (eds.)]. In: Climate Change 2013: The Physical Science Basis. Contribution of Working Group I to the Fifth Assessment Report of the Intergovernmental Panel on Climate Change [Stocker TF, Qin D, et al. (eds.)]. Cambridge University Press, Cambridge and New York.

IPCC (2018) Summary for policymakers. In: Global warming of $1.5^{\circ} \mathrm{C}$. An IPCC Special Report on the impacts of global warming of $1.5^{\circ} \mathrm{C}$ above pre-industrial levels and related global greenhouse gas emission pathways, in the context of strengthening the global response to the threat of climate change, sustainable development, and efforts to eradicate poverty [Masson-Delmotte V, Zhai P, et al. (eds.)]. World Meteorological Organization, Geneva.

Jacob D, Petersen J et al (2014) EURO-CORDEX: new high-resolution climate change projections for European impact research. Reg Environ Chang 14(2):563-578. https://doi.org/10.1007/s10113013-0499-2

Kang SM, Lu J (2012) Expansion of the Hadley cell under global warming: winter versus summer. J Clim 25(24):8387-8393. https://doi.org/10.1175/JCLI-D-12-00323.1

Kjellström E, Nikulin G, Strandberg G, Christensen OB, Jacob D, Keuler K, Lenderink G, van Meijgaard E, Schär C, Somot S, Sørland SL, Teichmann C, Vautard R (2018) European climate change at global mean temperature increases of 1.5 and $2{ }^{\circ} \mathrm{C}$ above pre-industrial conditions as simulated by the EURO-CORDEX regional climate models. Earth Syst Dyn 9:459-478. https://doi.org/10.5194/esd-9459-2018

Knutti R, Sedlacek J (2013) Robustness and uncertainties in the new CMIP5 climate model projections. Nat Clim Chang 3(4):369-373. https://doi.org/10.1038/nclimate1716

Kotlarski S, Keuler K, Christensen OB, Colette A, Déqué M, Gobiet A, Goergen K, Jacob D, Lüthi D, van Meijgaard E, Nikulin G, Schär C, Teichmann C, Vautard R, Warrach-Sagi K, Wulfmeyer V (2014) Regional climate modeling on European scales: a joint standard evaluation of the EURO-CORDEX RCM ensemble. Geosci Model Dev 7(4):1297-1333. https://doi.org/10.5194/gmd-7-12972014 
Kuglitsch FG, Toreti A, Xoplaki E, Della-Marta PM, Zerefos CS, Türkeş M, Luterbacher J (2010) Heat wave changes in the eastern Mediterranean since 1960. Geophys Res Lett 37(4):L04802+. https://doi.org/10.1029/2009GL041841

Kundzewicz ZW, Radziejewski M, Pinskwar I (2006) Precipitation extremes in the changing climate of Europe. Clim Res 31(1):51-58

Lehmann J, Coumou D, Frieler K, Alexey (2014) Future changes in extratropical storm tracks and baroclinicity under climate change. Environ Res Lett 9(8):084002+. https://doi.org/10.1088/1748-9326/ 9/8/084002

Lelieveld J, Hadjinicolaou P, Kostopoulou E, Chenoweth J, El Maayar M, Giannakopoulos C, Hannides C, Lange MA, Tanarhte M, Tyrlis E, Xoplaki E (2012) Climate change and impacts in the eastern Mediterranean and the Middle East. Clim Chang 114:667-687. https://doi.org/10.1007/s10584-012-0418-4

Lelieveld J, Proestos Y, Hadjinicolaou P, Tanarhte M, Tyrlis E, Zittis G (2016) Strongly increasing heat extremes in the Middle East and North Africa (MENA) in the 21st century. Clim Chang 137(1): 245-260. https://doi.org/10.1007/s10584-016-1665-6

Li L, Casado A, Dell'Aquila A, Dubois C, Elizalde A, L'Hévéder B, Lionello P, Sevault F, Somot S, Ruti P, Zampieri M (2011) Modelling of the Mediterranean climate system (chapter 7). In: Lionello P (ed) Mediterranean Climate Variability. Elsevier B.V, Amsterdam, pp 419-448

Lionello P, Scarascia L (2018) The relation between climate change in the Mediterranean region and global warming. Reg Environ Chang 18(5):1481-1493. https://doi.org/10.1007/s10113-018-1290-1

Lionello P, Abrantes F, Congedi L, Dulac F, Gacic M, Gomis D, Goodess C, Hoff H, Kutiel H, Luterbacher J, Planton S, Reale M, Schröder K, Struglia MV, Toreti A, Tsimplis M, Ulbrich U, Xoplaki E (2012) Introduction: Mediterranean climate: background information in Lionello P. (Ed.) The Climate of the Mediterranean Region. From the Past to the Future, Amsterdam: Elsevier (NETHERLANDS), XXXV-1XXX, ISBN:9780124160422

Luterbacher J, Xoplaki E (2003) 500-year winter temperature and precipitation variability over the Mediterranean area and its connection to the large-scale atmospheric circulation. In: Bolle HJ (ed) Mediterranean Climate. Regional Climate Studies. Springer, Berlin

Nikulin G, Lennard C, Dosio A, Kjellström E, Chen Y, Hänsler A, Marco K, Laprise R, Mariotti L, Maule CF, van Meijgaard E, Panitz H-J, John S, Somot S (2018) The effects of 1.5 and 2 degrees of global warming on Africa in the CORDEX ensemble. Environ Res Lett 13(6):065003+

Pal JS, Eltahir EAB (2016) Future temperature in southwest Asia projected to exceed a threshold for human adaptability. Nat Clim Chang 6:197-200. https://doi.org/10.1038/nclimate2833

Paxian A, Hertig E, Seubert S, Vogt G, Jacobeit J, Paeth H (2015) Present-day and future Mediterranean precipitation extremes assessed by different statistical approaches. 44(3-4):845-860.

Pendergrass AG, Knutti R, Lehner F et al (2017) Precipitation variability increases in a warmer climate. Sci Rep 7:17966. https://doi.org/10. 1038/s41598-017-17966-y

Philandras CM, Nastos PT, Kapsomenakis J, Douvis KC, Tselioudis G, Zerefos CS (2011) Long term precipitation trends and variability within the Mediterranean region. Nat Hazards Earth Syst Sci 11(12):3235-3250. https://doi.org/10.5194/nhess-11-3235-2011

Polade SD, Gershunov A, Cayan DR, Dettinger MD, Pierce DW (2017) Precipitation in a warming world: assessing projected hydro-climate changes in California and other Mediterranean climate regions. Sci Rep 7(1):10783+. https://doi.org/10.1038/s41598-017-11285-y

Räisänen J (2002) CO2-induced changes in interannual temperature and precipitation variability in 19 CMIP2 experiments. J Clim 15:23952411. https://doi.org/10.1175/1520-0442(2002)015<2395: CICIIT>2.0.CO;2

Riahi K, Grübler A, Nakicenovic N (2007) Scenarios of long-term socioeconomic and environmental development under climate stabilization. Technol Forecast Soc Change 74(7):887-935. https:// doi.org/10.1016/j.techfore.2006.05.026

Ruti PM, Somot S, Giorgi F et al (2016) Med-CORDEX initiative for Mediterranean climate studies. Bull Am Meteorol Soc 97(7):11871208. https://doi.org/10.1175/BAMS-D-14-00176.1

Sánchez E, Gallardo C, Gaertner MA, Arribas A, Castro M (2004) Future climate extreme events in the Mediterranean simulated by a regional climate model: a first approach. Glob Planet Chang 44(1-4):163180. https://doi.org/10.1016/j.gloplacha.2004.06.010

Sanderson B, Tebaldi C, O'Neill B (2016) What would it take to achieve the Paris temperature targets? Geophys Res Lett 43:7133-7142. https://doi.org/10.1002/2016GL069563

Shaw TA, Baldwin M, Barnes EA et al (2016) Storm track processes and the opposing influences of climate change. Nat Geosci 9:656-664. https://doi.org/10.1038/ngeo2783

Soares PMM, Cardoso RM (2018) A simple method to assess the added value using high-resolution climate distributions: application to the EURO-CORDEX daily precipitation. Int J Climatol 38:1484-1498. https://doi.org/10.1002/joc.5261

Somot S, Ruti P, Ahrens B, Coppola E, Jordà G, Sannino G, Solmon F (2018) Editorial for the Med-CORDEX special issue. Clim Dyn 51: 771-777. https://doi.org/10.1007/s00382-018-4325-x

Spinoni J, Barbosa P, Bucchignani E, Cassano J, Cavazos T, Christensen JH, Christensen OB, Coppola E, Evans J, Geyer B, Giorgi F, Hadjinicolaou P, Jacob D, Katzfey J, Koenigk T, Laprise R, Lennard CJ, Kurnaz L, Li D, Llopart M, McCormick N, Naumann G, Nikulin G, Ozturk T, Panitz HJ, Porfirio da Rocha R, Rockel B, Solman SA, Syktus J, Tangang F, Teichmann C, Vautard R, Vogt JV, Winger K, Zittis G, Dosio A (2019) Future global meteorological drought hotspots: a study based on CORDEX data. J Clim (under revision)

Tanahrte M, Hadjinicolaou P, Lelieveld J (2012) Intercomparison of temperature and precipitation datasets based on observations in the Mediterranean and the Middle East. J Geophys Res Atmos 117: D12102. https://doi.org/10.1029/2011JD017293

Trenberth KE, Dai A, Rasmussen RM, Parsons DB (2003) The changing character of precipitation. Bull Am Meteorol Soc 84(9):1205-1218. https://doi.org/10.1175/BAMS-84-9-1205

Tyrlis E, Lelieveld J, Steil B (2013) The summer circulation over the eastern Mediterranean and the Middle East: influence of the South Asian Monsoon. Clim Dyn 40(5-6):1103-1123. https://doi.org/10. 1007/s00382-012-1528-4

Ulbrich U, Leckebusch GC, Pinto JG (2009) Extra-tropical cyclones in the present and future climate: a review. Theor Appl Climatol 96(1): 117-131. https://doi.org/10.1007/s00704-008-0083-8

Ulbrich U, Xoplaki E, et al. (2013), eds: Regional assessment of climate change in the Mediterranean, Springer, Dordrecht, 9-52, ISBN 97894-007-5780-6

Vautard R, Gobiet A, Sobolowski S, Kjellström E, Stegehuis A, Watkiss P, Mendlik T, Landgren O, Nikulin G, Teichmann C, Jacob D (2014) The European climate under a $2{ }^{\circ} \mathrm{c}$ global warming. Environ Res Lett 9(3):034006+. https://doi.org/10.1088/1748-9326/9/3/034006

WCRP (2013) The World Climate Research Programme Achievements Report. WMO Report no 3/2013

Winter KJPM, Kotlarski S, Scherrer SC, Schär C (2017) The Alpine snow-albedo feedback in regional climate models. Clim Dyn 48: 1109-1124. https://doi.org/10.1007/s00382-016-3130-7

World Bank (2013) Turn down the heat: climate extremes, regional impacts, and the case for resilience. A report for the World Bank by the Potsdam institute for climate impact research and climate analytics. Washington, DC: World Bank

Zappa G, Hoskins BJ, Shepherd TG (2015) The dependence of wintertime Mediterranean precipitation on the atmospheric circulation response to climate change. Environ Res Lett 10:104012. https://doi. org/10.1088/1748-9326/10/10/104012 
Zittis G (2018) Observed rainfall trends and precipitation uncertainty in the vicinity of the Mediterranean, Middle East and North Africa. Theor Appl Climatol 134:1207. https://doi.org/10.1007/s00704017-2333-0

Zittis G, Hadjinicolaou P (2017) The effect of radiation parameterization schemes on surface temperature in regional climate simulations over the MENA-CORDEX domain. Int J Climatol 37(10):3847-3862. https://doi.org/10.1002/joc.4959

Zittis G, Hadjinicolaou P, Lelieveld J (2014) Role of soil moisture in the amplification of climate warming in the eastern Mediterranean and the Middle East. Clim Res 59(1):27-37. https://doi.org/10.3354/ cr01205

Zittis G, Hadjinicolaou P, Fnais M, Lelieveld J (2016) Projected changes in heat wave characteristics in the eastern Mediterranean and the Middle East. Reg Environ Chang 16(7):1863-1876. https://doi. org/10.1007/s10113-014-0753-2

Publisher's note Springer Nature remains neutral with regard to jurisdictional claims in published maps and institutional affiliations. 